\title{
VEGETATIVE SHOOTS IN THE TAXONOMY OF SEDGES (CAREX, CYPERACEAE)
}

\author{
A. A. Reznicek' and P. M. Catling ${ }^{2}$
}

\section{Summary}

The genus Carex includes species with true vegetative culms as well as species with vegetative shoots that lack elongate stems. Two terms relating to vegetative shoots in Carex are precisely defined. A brief review of the variation in vegetative shoot form is presented and examples of the utility of vegetative shoots in the taxonomy of Carex are given. Vegetative shoots should always be obtained by collectors of Carex, and they should be utilized in taxonomic work. Specific suggestions regarding collection and description are provided.

\section{Introduction}

"The neglect of vegetative characters has been one of the most serious errors in the history of classification, and has done much to delay the achievement of a natural system" (Davis and Heywood, 1963: 50).

Vegetative morphology and anatomy are useful in the taxonomy of Carex. This is documented by the extensive bibliography in Metcalfe (1971). The rhizomes of Carex have been well described and illustrated in the literature, and their use in taxonomy and identification is well known. However, the above-ground vegetative shoots are typically not mentioned in descriptions and are rarely used in taxonomy and identification. This is surprising, because vegetative shoots possess diagnostically valuable characters and are easier to observe than rhizomes. Even keys to Carex emphasizing vegetative characters (see Neumann, 1952; Damman, 1964; Johnson, 1964; Alekseev and Novikov, 1971; Jermy, Chater and David, 1982; and Thomas, 1982 for good recent examples), do not take full advantage of characters of vegetative shoot structure and form. Neglect of these characters is due partly to the general notion that the vegetative shoots of Carex are only false stems composed of overlapping leaf sheaths.

Our observations indicate that true vegetative stems do occur in some species of Carex and that vegetative shoots of all kinds are of considerable taxonomic importance. In addition, the occurrence of vegetative shoots in Carex has potential ecological and evolutionary significance. The objectives of this paper are: 1 , to clarify terminology associated with vegetative shoots; 2 , to describe variation in vegetative shoot form and demonstrate its taxonomic utility; and 3, to provide suggestions for improved description writing and preparation of herbarium specimens.

\section{Terminology}

A number of authors have illustrated or noted nodes on vegetative shoots of Carex (see, for example, the illustrations of Carex chordorrhiza L. f. (Schkuhr, 1801: t. Ii, fig. 31), and C. muskingumensis Schwein. (Boott, 1858: t. 54, sub C. arida)). Goodenough (1794) described the "stoloniferous" habit of $C$. limosa L. The significance of these observations,

1 University of Michigan Herbarium, North University Building, Ann Arbor, MI 48109, U.S.A.

Agriculture Canada, Biosystematics Research Institute, Ottawa, Ontario K1A 0C6, Canada. 
however, was not realized. Holm (1896) appears to be the first to discuss nodes and axillary buds in vegetative shoots of Carex, but he did not pursue these observations further. Our recent work confirms that some vegetative shoots of Carex have nodes, internodes, and dormant axillary buds at the nodes, as well as apical meristems. These apical meristems and axillary buds are capable of regrowth, doing so regularly in a few species such as $C$. chordorrhiza and $C$. limosa, and occasionally in other species, as noted for $C$. longii Mackenzie, $C$. projecta Mackenzie, $C$. tribuloides Wahlenb., and $C$. vexans F. J. Herm. by Weatherby $(1945)$ and Eaton $(1959,1960)$. These vegetative shoots are true stems, not false stems formed only of overlapping sheaths.

False stems, more common in sedges than true vegetative stems, can be recognized because the leaf bases are borne very close together, as a rosette, on a tightly contracted stem without discernible internodes. Even in species with long-creeping, pseudomonopodial rhizomes such as the North American Carex foenea Willd. and the Eurasian C. arenaria $\mathrm{L}$., the transition from elongated rhizome internodes bearing sheaths to the tightly contracted, leaf-bearing stem is abrupt.

The distinction between the two types of vegetative shoots appears to be clear-cut, but careful observation is sometimes needed to make the distinction. A few species, such as Carex limosa, develop vegetative stems after their fruits mature. In other cases, young flowering culms with inflorescences not yet exserted from the upper sheaths and flowering culms with inflorescences damaged and thus not protruding beyond the upper sheaths can resemble vegetative stems. Further, under certain environmental conditions, such as rapidly accumulating sand or rapidly growing sphagnum, more or less erect rhizomes may occur, and these, bearing vegetative shoots at their apex, may be mistaken in herbarium material for short vegetative stems. Presently, we know of no case where species normally producing vegetative stems sometimes develop false stems in their place, or vice-versa. A few species, such as the South American C. andina Phil., C. aphylla Kunth, and their relatives, and possibly others, rarely, if ever, produce vegetative shoots of any kind as adult plants.

While the features of the vegetative shoot, including leaves, sheaths, ligules, etc., have the same terminology as flowering culms, we would like to define the following terms for describing the form of vegetative shoots and recommend their use in keys and descriptions. We do not favor new terminology, but clearly more precision is needed. Only the term pseudoculm, analogous to pseudostem as used to describe the false stems formed of overlapping leaf sheaths in Musa and its relatives, is evidently defined for the first time. While the terminology is intended specifically for Carex, it may prove to have wider applicability in the Cyperaceae. For example, some species of Scirpus sensu lato (such as $S$. fluviatilis (Torrey) Gray) have vegetative stems.

Vegetative shoots in Carex have been traditionally termed "sterile shoots" or "sterile culms" (e.g., Kükenthal, 1909; Mackenzie, 1931, 1935). This is not strictly correct as perennial vegetative shoots may flower in subsequent years. Therefore, we prefer to use the adjective vegetative in our terminology. Furthermore, the terms "sterile shoot" and "sterile culm" have not been defined or applied precisely. A few authors, such as Mackenzie $(1931,1935)$ who used both terms, applied them indiscriminately. The term "false stem" has also been used by some authors, but applied inappropriately to vegetative culms.

Most glossaries define culm as the specialized stem of grasses and sedges. A few glossaries, e.g., Radford et al. (1974), define it as the flowering stem of grasses and sedges. We follow the former definition, recognizing the distinctive morphology of aerial stems, both vegetative and flowering, of grasses and sedges.

Vegetative culm: The elongate stem, with nodes and internodes, of a vegetative shoot in Carex.

Pseudoculm: The more or less rigid, stem-like structure formed only of overlapping leaf sheaths, in vegetative shoots of Carex species without vegetative culms. 


\section{Variation in Vegetative Shoot Form}

Vegetative shoots are rarely mentioned in descriptions and often not collected. Hence, a comprehensive survey of morphological variation in vegetative culms and pseudoculms is not yet possible. Nevertheless, a brief survey, concentrating on North American species, is illuminating.

Vegetative culms. - Vegetative culms occur in a number of unrelated sections in two of the three subgenera of Carex, subgenus Carex and subgenus Vignea. We have not yet found them in subgenus Indocarex. Vegetative culms are mostly erect and usually bear more leaves than flowering culms. These leaves are often tristichous and usually clustered on the upper part of the culm. Typical examples of vegetative culms include the very tall, annual vegetative culms of $C$. sartwellii Dewey of North America and $C$. disticha Hudson of Eurasia and the shorter culms of many species of section Ovales (Kunth) Christ.

A few major departures from this morphology occur. In the circumboreal Carex limosa, the vegetative culms are ascending from a more or less prostrate base (Holm, 1922). They do no develop fully until after the flowering culms have ripened fruit, and early in the season these culms are short and may resemble pseudoculms. The vegetative culms of the circumboreal $C$. chordorrhiza are similar in growth form to those of $C$. limosa, but much longer. When fully developed, they are more or less prostrate. In both species, next season's vegetative and flowering culms grow from dormant buds in the leaf axils along the culm and from the apical meristem. These leafy vegetative culms have been called rhizomes by some authors (e.g., Boivin, 1979; Jermy, Chater and David, 1982). Although the transition from underground rhizomes to aerial culms can be gradual in both $C$. chordorrhiza and C. limosa, we prefer to call the aerial structures culms because they are leafy when first formed. If buried by litter or growing moss, the vegetative culms lose their leaves, root at the nodes, and resemble rhizomes. The term stolon may be applied to these organs (see discussion in Stevens, 1966) but they cannot be distinguished from erect vegetative culms unless they become buried. The North American $C$. assiniboinensis W. Boott does have vegetative culms differentiated into tip-rooting stolons up to $2 \mathrm{~m}$ long with abruptly reflexed, reduced leaves on the distal portions (Tolstead, 1946; Bernard, 1959). This species also produces erect pseudoculms and, to our knowledge, it is the only species of Carex that produces both vegetative culms and pseudoculms.

Vegetative culms of most species are annual. However, as noted above, those of Carex limosa, C. chordorrhiza, and doubtless other species are perennial. Several species in sect. Ovales have annual vegetative culms that can become perennial in certain circumstances and may be important in vegetative propagation (Weatherby, 1945; Eaton, 1959, 1960). An annual vegetative culm of C. trichocarpa Willd. is illustrated in Fig. 1, E-G.

Pseudoculms. - Pseudoculms are widespread in all subgenera of Carex. They range in thickness from several $\mathrm{cm}$ in the Eurasian and African C. acutiformis Ehrh. to less than 1 $\mathrm{mm}$ in tiny species such as the North American $C$. eburnea Boott. Pseudoculms vary in length from $5 \mathrm{dm}$ in some large species such as the North American $C$. lacustris Willd. to less than a few $\mathrm{cm}$ in smaller species. Leaves are typically more numerous on pseudoculms than on flowering culms. Usually a pseudoculm appears to have a loose rosette of leaves at its apex because all leaf sheaths are about the same length. In a few species, such as the North American C. careyana Dewey, C. plantaginea Lam., C. platyphylla Carey, and others in section Careyanae Kük., the sheaths are so short and tear so readily that pseudoculms are almost nonexistent and the vegetative shoot is a nearly flat rosette.

Vegetative shoots with pseudoculms are either annual or perennial depending on the species. Perennial vegetative shoots with pseudoculms may flower and die after they are a year or more old. How long they can live in the vegetative state is uncertain except in a few species (Bernard, 1976), although our observations suggest that most live for only about two years. Normally a single flowering culm is produced from the apical meristem, but in some species of sect. Careyanae including C. careyana, C. plantaginea, and C. platyphylla, 


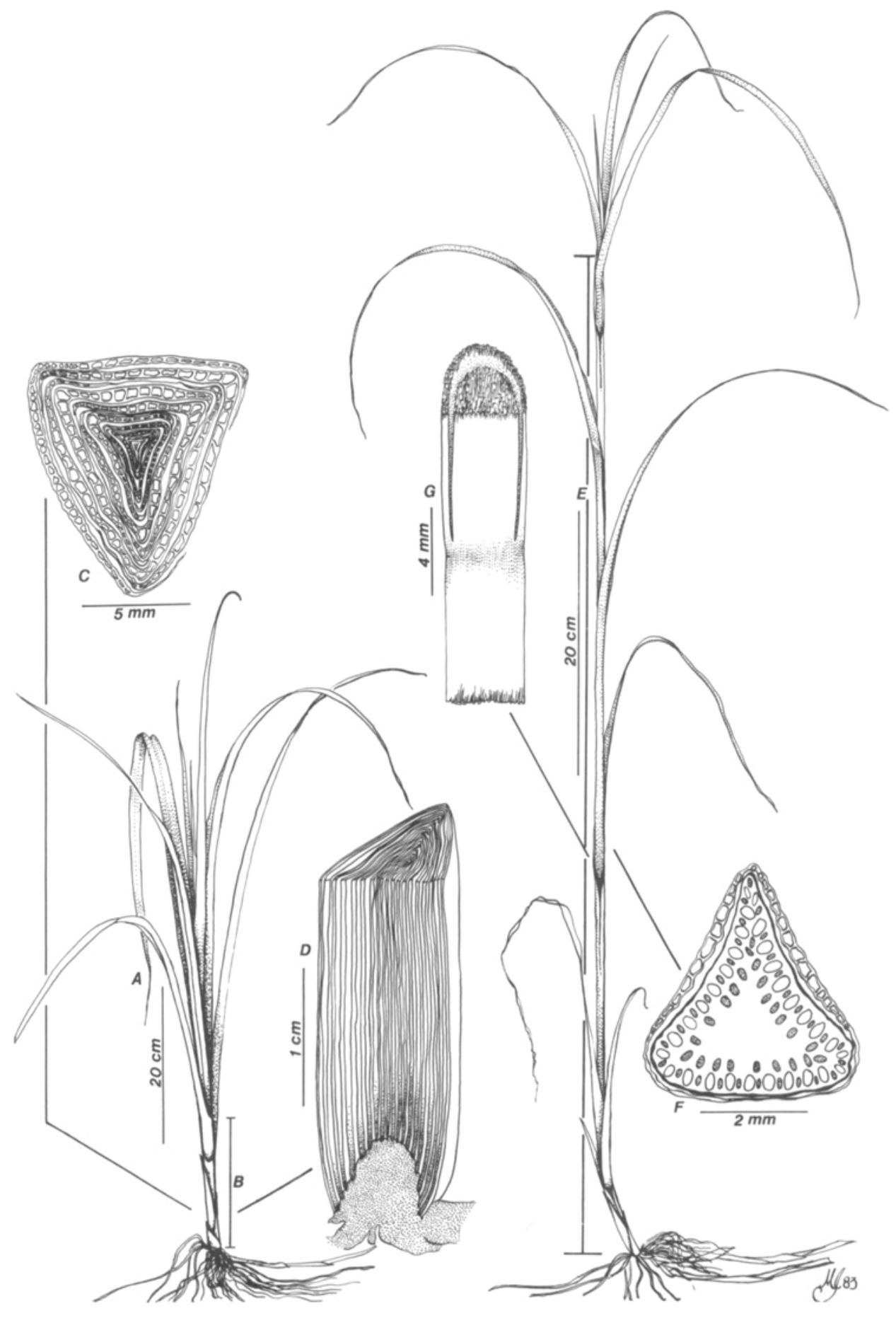

Fig. 1. Vegetative shoots in Carex. A-D, C. hyalinolepis: A, vegetative shoot; B, pseudoculm; C, cross-section of pseudoculm; $\mathrm{D}$, longitudinal section of pseudoculm. E-G, C. trichocarpa: $\mathrm{E}$, vegetative culm; $F$, cross-section of vegetative culm; $G$, longitudinal section through node of vegetative culm. 
both the apical meristem and the lateral buds in the leaf axils may produce flowering culms. A perennial vegetative shoot with pseudoculm of $C$. hyalinolepis Steudel is illustrated in Fig. 1, A-D.

\section{Taxonomic Significance}

Vegetative culms occur in several dissimilar and quite unrelated sections in two subgenera of Carex, and thus have probably evolved independently several times. However, within related sections, their presence and morphology provide characters that can be useful indicators of species relationships. In the notoriously difficult section Ovales, the similar, and presumably closely related, $C$. tribuloides, $C$. projecta, $C$. cristatella Britton, and $C$. muskingumensis of eastern North America have strongly dimorphic flowering and vegetative culms with well developed, tall, leafy vegetative culms which are quite different from those of other species in section Ovales (Mackenzie, 1931). In putative hybrids of sections Paludosae (Fries) Christ and Carex involving species with vegetative culms and those with pseudoculms, e.g., $C . \times$ caesariensis Mackenzie (C. trichocarpa $\times$ C. lanuginosa Michaux), the hybrids retain vegetative culms. The vegetative culm thus is a useful feature in the study of hybrids (Reznicek and Catling, 1985; unpublished data).

Pseudoculms, though less diverse in morphology than vegetative culms, are also useful in taxonomy. For example, the very similar eastern North American $C$. lacustris and $C$. hyalinolepis, regarded as conspecific by some authors (Gleason, 1952; Gleason and Cronquist, 1963), can easily be separated in vegetative condition using pseudoculm height (Reznicek and Catling, 1986).

Examination of leaves of vegetative shoots may also disclose new characters. In addition to differences in number and placement, the leaves of vegetative shoots and flowering culms are often dimorphic. This dimorphism is usually subtle, such as differences in maximum leaf length and width. Occasionally, it may be marked, as in the unique Tonkin endemic Carex kucyniakii Raymond, where the flowering culm has only bladeless sheaths while the vegetative shoot has a single, very broad, pseudopetiolate leaf (Raymond, 1959).

Certain vegetative features, such as leaf folding, sheath morphology, and ligule characters may be more easily studied on vegetative shoots than on flowering culms. On flowering culms, ligules in particular can show substantial variation depending on the position of the leaf (Cusset and Tran, 1965). Our observations suggest that ligules on vegetative shoots are less variable.

\section{Collection and Description}

Vegetative shoots are diverse in form and valuable in the taxonomy of Carex. The value of vegetative shoots will increase when they are better known through careful observations, improved collections and complete descriptions.

Presumably because so many floras and monographs emphasize that Carex cannot be reliably determined without fruit, there has developed the notion that fruiting culms are all that are required for adequate herbarium specimens of Carex. We strongly urge that, in addition to fruiting culms and rhizomes, collectors obtain complete vegetative shoots, even when these are large and difficult to press. A good method for preparing herbarium specimens of the larger species is to lay one vegetative shoot and one fruiting culm oriented in the same direction and close together near the middle of the newsprint, with the usually shorter fertile culm to the right and the roots and rhizomes near either the top or the bottom edge of the newsprint. Then fold the sterile shoot towards the left and the fertile culm towards the right, as tightly as needed to fit them on the sheet. With even the very largest specimens, both shoots can be accommodated on the sheet leaving room above the label to add supplementary sections of fruiting culms. In those species where vegetative shoots do not fully develop until after the fruit is mature, it may be impossible to have 
both mature fruit and mature vegetative shoots on the same specimen, but, enough fruits usually persist on overmature fruiting culms to make a late-collected specimen adequate.

Descriptions should include at least the basic information about vegetative shoots, including total height (measured with the leaves fully extended), leaf arrangement (on vegetative culms), number of leaves, pseudoculm or culm width and height, whether the vegetative shoots are annual or perennial (in seasonal climates), patterns of regrowth from dormant buds if the shoots are perennial, and the habit of the vegetative shoot, whether erect, ascending, or prostrate. Other distinctive features of vegetative shoots, including pubescence, angularity of culms, hollow culms, and colour of sheath apices, among many others, should also be noted. Since the apex of the vegetative culm is enclosed by sheaths, culm height cannot be measured without dissection. We suggest that the height to the uppermost visible sheath apex be used as an estimator of height. Upper leaves are usually clustered near the apex of the vegetative culm and their sheaths are reduced in length, so this measure will approximate culm height to within a few $\mathrm{cm}$. Pseudoculm height is measured in the same manner.

If the vegetative shoots differ from the flowering culms in features of sheaths, ligules, leaf blade length and width, etc., descriptions should include data for both. Anatomical studies also should encompass both vegetative shoots and flowering culms, as these may differ.

Recognition of vegetative characters with diagnostic value would be especially useful in Carex. Many species, particularly large marsh dominants, occur in extensive stands with few or no flowering culms. Also, many field ecological studies are carried out when carices are not in mature fruit. Characters that would allow reliable determination of these species in vegetative condition would be helpful to field biologists. As in some treatments of Salix (e.g., Fernald, 1950), keys to vegetative as well as fruiting Carex may become possible with collection of more extensive data on vegetative shoots.

\section{Acknowledgments}

We thank Peter Ball, Jacques Cayouette, Lisa Standley, and Edward Voss for their helpful comments on the manuscript. We are grateful to Marcel Jomphe for drawing Fig. 1 and Susan Reznicek for making minor modifications to it.

\section{Literature Cited}

Alekseev, Y. E. and V. S. Novikov. 1971. Opredelitel' osok srednei polosy Evropeiskoi chasti SSSR po vegatetivnym organam. Nauka, Moskva. $80 \mathrm{pp}$.

Bernard, J. M. 1976. The life history and population dynamics of shoots of Carex rostrata. J. Ecol. 64: 1045-1048.

Bernard, J. P. 1959. Le Carex assiniboinensis Boott et sa forme stolonifere. Nat. Can. 86: 11-19.

Boivin, B. 1979. Flora of the Prairie provinces, Part IV. Provancheria 5: 1-189. Reprinted from Phytologia 42: 1-24, 385-414; 43: 1-106, 223-251.

Boott, F. 1858. Illustrations of the genus Carex, Part 1. William Pamplin, London. xii +74 pp., $200 \mathrm{pl}$.

Cusset, F. and T. T. H. Tran. 1965. La ligule de la feuille végétative des Carex. Bull. Soc. Bot. France 112: 42-54.

Damman, A. W. H. 1964. Key to the Carex species of Newfoundland by vegetative characteristics. Can. Dept. Forestry Publ. 1017. 39 pp.

Davis, P. H. and V. H. Heywood. 1963. Principles of angiosperm taxonomy. Oliver and Boyd, Edinburgh and London. $\mathrm{xx}+558 \mathrm{pp}$.

Eaton, R. J. 1959. Additional note on vegetative reproduction in Carex tribuloides and C. projecta. Rhodora 61: 294-295.

1960. Vegetative reproduction in Carex longii and C. vexans. Rhodora 62: 338-339.

Fernald, M. L. 1950. Gray's manual of botany, Ed. 8. Amer. Book Co., New York. lxiv + 1632 pp.

Gleason, H. A. 1952. The New Britton and Brown illustrated flora of the northeastern United States and adjacent Canada. New York Bot. Gard., New York. 3 vols. 
- and A. Cronquist. 1963. Manual of vascular plants of northeastern United States and adjacent Canada. Van Nostrand, Princeton. li +810 pp.

Goodenough, S. 1794. Observations on the British species of Carex. Trans. Linn. Soc. 2: 126-211.

Holm, T. 1896. Studies on the Cyperaceae. I. On the monopodial ramification in certain North American species of Carex. Amer. J. Sci. 1: 348-350.

1922. Studies in the Cyperaceae. XXXIV. Carices aeorastachyae: Glaucescentes NOB., and Limosae NOB. Amer. J. Sci. 3: 260-268.

Jermy, A. C., A. O. Chater and R. W. David. 1982. Sedges of the British Isles. Botanical Society of the British Isles, London. 268 pp.

Johnson, W. M. 1964. Field key to the sedges of Wyoming. Univ. Wyoming Agr. Exp. Sta. Bull. 419. $239 \mathrm{pp}$.

Kükenthal, G. 1909. Cyperaceae-Caricoideae. In: A. Engler (ed.), Das Pflanzenreich, IV. 20. Heft 38, pp. 1-824. Wilhelm Engelmann, Leipzig.

Mackenzie, K. K. 1931. Cyperaceae, tribe 1, Cariceae. N. Amer. Flora 18: 1-168.

- 1935. Cyperaceae, tribe 1, Cariceae. N. Amer. Flora 18: 169-478.

Metcalfe, C. R. 1971. Anatomy of the monocotyledons. V. Cyperaceae. Clarendon Press, Oxford. 612 pp. 69 pl.

Neumann, A. 1952. Vorläufiger Bestimmungsschlüssel für Carex-Arten Nordwestdeutschlands im Blütenlosen Zustande. Mitt. Florist. -Soziol. Arbeitsgem. 3: 44-77.

Radford, A. E., W. C. Dickison, J. R. Massey and C. R. Bell. 1974. Vascular plant systematics. Harper and Row, New York. 891 pp.

Raymond, M. 1959. Carices indochinensis necnon siamensis. Mém. Jard. Bot. Montréal 53: 1-125.

Reznicek, A. A. and P. M. Catling. 1985. The status and identity of Carex caesariensis (Cyperaceae). Rhodora 87: 529-537.

- and - 1986. The status and distribution of Carex subimpressa Clokey (Cyperaceae). Canad. J. Bot. 64: 227-232.

Schkuhr, C. 1801. Beschreibung und Abbildung der theils bekannten, theils noch nicht beschriebenen Arten von Riedgräsern nach eigenen Beobachtungen und vergrösserter Darstellung der kleinsten Theile. Wittenberg. $128 \mathrm{pp} ., 54 \mathrm{pl}$.

Stevens, O. A. 1966. Rhizomes, stolons, and roots. Castanea 31: 140-145.

Thomas, W. W. 1982. Identification of the species of Carex in Michigan's upland deciduous forests: A key stressing vegetative features. Michigan Bot. 21: 131-139.

Tolstead, W. L. 1946. Stolons of Carex assiniboinensis Boott in Iowa. Amer. Midl. Nat. 35: 797.

Weatherby, C. A. 1945. Vegetative reproduction in Carex tribuloides and C. projecta. Rhodora 47: 39-40. 